\title{
Analysis of Achievements in Sputum Case Finding for 1969
}

\author{
Nak Chin Chung, M.D., M.P. H., Ph. D. \\ Chief, Tuberculosis Prevention Section, Ministry of Health and Social Affairs
}

\section{$<$ 종 합>}

전염 병 관리의 기본 목적은 지역사회의 전염을 신속히 감소시키는데 있다. 이 목적을 달성하기 위하여 전염원의 대부분을 발견하여야 하고 이들 발견된 자에게 적절하고 효과적인 치료를 가하여야 한다.

통계조사에 의하면 개방성 결핵환자의 약 $90 \%$ 는 호흡기증상(기침, 객담)이 있으며 이들중 균 배출양이 많은 고도 전염성 환자는 쉅게 직접 도말검사에서 결핵균이 증명된다.

정부는 결핵만연의 근원이 되는 전염성 환자 발견에 박차를 가하기 위하여 객담검진을 통한 환자 발견사 업을 1967년말 부티 전개하였으며 1968년말까지 23,657명 1969년에는 24,313명을 발견하였다.

객담 검진 사업을 보다 효율적으로 하기 위한 방안을 모색하기 위하여 1969년 사업실적을 지역, 보건소, 보건지소 별로 분석하였다.

1) 총 665,750 명의 객담 검사에서 $3.7 \%$ 인 24,313 명을 발견하였으며 이는 추정된 전국 양성환자 226,000 의 $11 \%$ 에 해당한다.

2) 지역별 발견율 비교에서 대도시 $2.4 \%$, 중도시 $2.7 \%$, 소도시 $2.2 \%$, 군 $4.1 \%$ 로서 군(농촌)지역이 가장 고율이였다.

3) 인구 1,000 명당 발견비율은 0.83 이었고 전체 발견 환자의 $83.6 \%$ 가 군 보건소에서 발견되었다.

4) 군부 지역에 있어서 면요원 1인당 년간 12.4 명을 발견했으며 경북도가 17.5 명으로 가장 성적이 좋았 고 경남도가 7.7 명으로 가장 부진하였다.

5) 객담수집 건수가 많을 수록 많은 환자가 발견되는 것이나 수집된 객담의 질 여하에 따라 발견율은 자 우된다.

본 사업의 개선을 위하여 가장 필요한 고려사항은 일선 사업요원의 사기 앙양과 요원의 훈련 및 계속적 인 지도 감독이다.

The basic principle of communicable diseases control is to reduce as quickly as possible the transmission of the infection in the community. To achieve this, a high proportion of the spreaders of the organisms must be identified and all the cases discovered must be provided with effective and adequate treatment. It is estimated that there are about 226,000 infectious cases in Korea. In view of the vastness of the need and the limited resources available, the Government introduced the primary sputum test as a means of case-finding in late 1967. This method is not only simple and cheap, but also easily carried out by lay workers with a short period of training.

In the year of 1969, a total of 665,750 specimens were collected and 24,313 cases were discovered. To find out the factors related to the case-finding for further improvement, the writer has analysed the achievements in 1969 by province, health centre and myon sub-centre as follows. 


\section{PART 1}

\section{Analysis by Health Centres of Different Categories}

During 1969 a total of 665,750 sputum specimens were collected and examined. As a result, 24, 313 cases were discovered, a discovery rate of $3.7 \%$. The achievements are analysed by category of health centres, i. e., health centres in large, medium and small cities and guns, and shown in Table 1, which is further summarized below:

\begin{tabular}{l|rr|rr|r}
\hline \hline $\begin{array}{l}\text { Cities of } \\
\text { different } \\
\text { size and } \\
\text { guns }\end{array}$ & $\begin{array}{l}\text { No. of speci- } \\
\text { mens collected }\end{array}$ & \begin{tabular}{l} 
Total $\begin{array}{l}\text { Per H. C. } \\
\text { average }\end{array}$ \\
\cline { 2 - 6 } discovered
\end{tabular} & $\begin{array}{l}\text { Total } \\
\text { Per H. C. } \\
\text { average }\end{array}$ & $\begin{array}{l}\text { Disco- } \\
\text { very } \\
\text { rate } \\
(\%)\end{array}$ \\
\hline $\begin{array}{c}\text { Large } \\
\text { cities }\end{array}$ & 93899 & 3478 & 2209 & 82 & 2.4 \\
$\begin{array}{c}\text { Medium } \\
\text { cities }\end{array}$ & 45105 & 4511 & 1222 & 122 & 2.7 \\
$\begin{array}{c}\text { Small } \\
\text { cities }\end{array}$ & 25508 & 1882 & 569 & 41 & 2.2 \\
$\begin{array}{c}\text { Guns } \\
\text { Total }\end{array}$ & 501238 & 3580 & 20313 & 145 & 4.1 \\
& 665750 & 3486 & 24313 & 127 & 3.7 \\
\hline
\end{tabular}

As seen above, health centres in medium cities collected the largest average number of specimens among the others, and this was due to the sputum case-finding campaigns conducted in some of the medium cities, i. e., Suwon, Chunchon and Mokpo. If these three cities are excluded, the average number of specimens collected per H.C. becomes 1568, which is the smallest in the whole country and the average number of cases discovered becomes 44 , about the same as in small cities.

When analysis is to be made of the achievements, the number of work units involved must be taken into consideration. For example, in large cities, such as Seoul, Pusan, Taegu, Inchon, there exist a multiple number of health centres, whereas other cities have only one health centre. Under the gun health centres, there are on average 10 health subcentres with at least one health aides available. In the table below, the percentage distributions of specimens collected and of cases discovered are shown in contrast to the percentage distribution of the number of health centres:

\begin{tabular}{l|r|c|c}
\hline \hline $\begin{array}{l}\text { Cities of } \\
\text { different size } \\
\text { and guns }\end{array}$ & $\begin{array}{c}\text { Health } \\
\text { centres } \\
(\%)\end{array}$ & $\begin{array}{c}\text { Specimens } \\
\text { collected } \\
(\%)\end{array}$ & $\begin{array}{c}\text { Cases } \\
\text { discovered } \\
(\%)\end{array}$ \\
\hline Large cities & 14.1 & 14.1 & 9.1 \\
Medium cities & 5.2 & 6.8 & 5.2 \\
Small cities & 7.3 & 3.8 & 2.3 \\
Guns & 73.3 & 75.3 & 83.6 \\
Total & 99.9 & 100.0 & 100.0 \\
\hline
\end{tabular}

It is readily seen above that the number of specimens collected was roughly in proportion to the number of health centres, but as far as the number of cases discovered is concerned, the distribution is slightly distorted. In general, the gun health centres contributed realtively more to the total than those in cities, and this is due to the higher discovery rate in guns. In other words, workers in the gun health centres or myon/eup subcentres collected the sputum more selectively, provided that the technique in microscopic examination is the same as elsewhere.

Again, the size of population served must be taken into consideration for evaluation of the accomplishment. The following table presents the number of cases discovered per 1000 population:

\begin{tabular}{l|r|r|r}
\hline $\begin{array}{l}\text { Cities of } \\
\text { different } \\
\text { size and } \\
\text { guns }\end{array}$ & $\begin{array}{c}\text { No. of } \\
\text { population }\end{array}$ & $\begin{array}{l}\text { No. of cases } \\
\text { discovered }\end{array}$ & $\begin{array}{l}\text { No. of cases } \\
\text { discovered } \\
\text { per 1000 } \\
\text { pop. }\end{array}$ \\
\hline Large cities & 7552,273 & 2209 & 0.29 \\
Medium cities & 1199,693 & 1222 & $1.02^{*}$ \\
Small cities & $977,6: 6$ & 569 & 0.58 \\
Guns & 19478,254 & 20,313 & 1.04 \\
Total & 23207,856 & 24,313 & 0.83 \\
\hline
\end{tabular}

*2.34 for Suwon, Chunchon and Mokpo combined and 0.40 for the remaining medium cities.

It is noted above that the number of cases discovered per 1000 population is higher for health centres in guns and medium cities. However, if the three cities where case-finding campaign was conducted are seperated, the per 1000 case rate becomes only 0.40 for those in medium cities, which is even lower than the rate for those in small cities. The rate for 
the whole country is 0.83 per 1000 which is much smaller than the target of $1.5 \sim 2.0$ cases per 1000 as recommended by WHO, and even the gun health centres reached only two thirds of the target of 1.5 cases.

Finally, we have to know how many out of the estimated total of cases in the communities have been discovered, and analysis is made as follows:
The proportion of cases discovered among the total estimated is $10.1 \%$ for the country as a whole. It is as high as $41.0 \%$ for those in the medium cities, and this is mainly because of the sputum casefinding campaign conduted in three cities and the relativery low prevalence rate in the medium cities as revealed by the first prevalence survey. If these three cities are exculuded, the case rate becomes $15.5 \%$, which

\begin{tabular}{l|r|c|c|c|c}
\hline \hline $\begin{array}{l}\text { Cities of different size } \\
\text { and guns }\end{array}$ & $\begin{array}{l}\text { No. of popul. } \\
\text { 5 yrs \& above }\end{array}$ & $\begin{array}{l}\text { Prevalence rate } \\
\text { of cases }\end{array}$ & $\begin{array}{l}\text { Estimated total } \\
\text { No. of cases }\end{array}$ & $\begin{array}{l}\text { No. of cases } \\
\text { discovered }\end{array}$ & $\begin{array}{l}\text { Proportion of } \\
\text { cases discovered }\end{array}$ \\
\hline Large cities & $6,494,955$ & 0.7 & 45,464 & 2,209 & 4.9 \\
Medium cities & $1,031,736$ & 0.3 & 2,982 & 1,222 & $41.0^{*}$ \\
Small cities & 878,503 & 1.0 & 8,785 & 569 & 6.5 \\
Guns & $16,751,298$ & 1.1 & 184,264 & 20,313 & 11.0 \\
Total & $25,118,756$ & 0.94 & 241,495 & 24,313 & 10.1 \\
\hline
\end{tabular}

*90. 8 for Suwon. Chunchon and Mokpo combined and 15.5 for the remaining medium cities.

Table 1. Achievements in Sputum Case-Finding by Categories of Health Centres, 1969

Large cities

\begin{tabular}{l|c|c|c|c}
\hline \multicolumn{1}{c|}{ H. C. } & $\begin{array}{l}\text { No. of specimens } \\
\text { collected }\end{array}$ & $\begin{array}{c}\text { No. of cases } \\
\text { discovered }\end{array}$ & Discovery rate (\%) & $\begin{array}{l}\text { No. of cases disco- } \\
\text { vered per 1000 } \\
\text { population }\end{array}$ \\
\hline Seoul(9)* & 23,836 & 857 & 3.6 & 0.23 \\
Pusan(6) & 49,145 & 868 & 1.8 & 0.61 \\
Inchon(4) & 3,539 & 92 & 2.6 & 0.17 \\
Taejon & 858 & 28 & 3.3 & 0.08 \\
Taegu(5) & 13,634 & 254 & 1.9 & 0.30 \\
Chunju & 770 & 43 & 5.6 & 0.19 \\
Kwangju & 2,117 & 67 & 3.2 & 0.17 \\
Total & 93,899 & 2,209 & 2.4 & 0.29 \\
Per H. C. average & 3,478 & 82 & 2.4 & \\
\hline
\end{tabular}

Medium cities

\begin{tabular}{l|r|r|r|r}
\hline \hline Suwon & 6,646 & 216 & 3.2 & 1.68 \\
Chunchon & 16,605 & 353 & 2.1 & 3.52 \\
Wonju & 677 & 23 & 3.4 & 0.22 \\
Chungju & 821 & 26 & 3.2 & 0.32 \\
Gunsan & 1,556 & 28 & 1.8 & 0.27 \\
Mokpo & 10,875 & 347 & 3.2 & 2.14 \\
Yosu & 1,657 & 50 & 3.1 & 0.49 \\
Masan & 1,356 & 65 & 4.8 & 0.42 \\
Chinju & 1,526 & 46 & 3.0 & 0.43 \\
Ulsan & 3,386 & 68 & 2.0 & 0.60 \\
Total & 45,105 & 1,222 & 2.7 & 1.02 \\
Per H. C. average & 4,511 & 122 & 2.7 & \\
\hline
\end{tabular}


Small cities

\begin{tabular}{|c|c|c|c|c|}
\hline H.C. & $\begin{array}{l}\text { No. of specimens } \\
\text { collected }\end{array}$ & $\begin{array}{l}\text { No. of cases } \\
\text { discovered }\end{array}$ & Discovery rate $(\%)$ & $\begin{array}{l}\text { No. of cases disco- } \\
\text { vered per } 1000 \\
\text { population }\end{array}$ \\
\hline Wijongboo & 736 & 27 & 3.7 & 0.36 \\
\hline Kangneung & 928 & 36 & 3.9 & 0.55 \\
\hline 'Solkcho & 3644 & 52 & 1.4 & 0.82 \\
\hline Choongju & 877 & 24 & 2.7 & 0.19 \\
\hline Chunan & 676 & 39 & 5.8 & 0.55 \\
\hline Iri & 833 & 28 & 3.4 & 0.36 \\
\hline Soonchon & 4374 & 72 & 1.6 & 0.91 \\
\hline Kimchon & 1491 & 50 & 3.4 & 0.88 \\
\hline Andong & 1148 & 43 & 3.7 & 0.67 \\
\hline Pohang & 2247 & 39 & 1.7 & 0.59 \\
\hline Kyongju & 3566 & 41 & 1.1 & 0.48 \\
\hline Choongmu & 2281 & 36 & 1.6 & 0.71 \\
\hline Samchonpo & 1419 & 42 & 3.0 & 0.78 \\
\hline Cheju & 1288 & 40 & 3.1 & 0.46 \\
\hline Total & 25,508 & 569 & 2.2 & 0.58 \\
\hline Per H.C. average & 1882 & 41 & 2.2 & \\
\hline \multicolumn{5}{|l|}{ Gun } \\
\hline Total $(140)$ & 501,238 & 20,313 & 4.1 & 1. 04 \\
\hline Per H.C. average & 3580 & 145 & 4.1 & \\
\hline \multicolumn{5}{|l|}{ Whole country. } \\
\hline Total (191) & 665,750 & 24,313 & 3.7 & 0.83 \\
\hline $\begin{array}{l}\text { Per H. C. average } \\
\text { Monthly per myon } \\
\text { average }\end{array}$ & $\begin{array}{r}3486 \\
291\end{array}$ & $\begin{array}{r}127 \\
1.1\end{array}$ & 3.7 & \\
\hline
\end{tabular}

*Figures in the parentheses are the number of health centree.

is still higher than the other cities and guns. In this analysis, the health centres in small cities do no longer show the smallest proportion, instead, a proportion larger than the large cities.

In conclusion, a total of 24313 cases were discovered by the 192 health centres as a result of sputum collection and examination in 1969, the rate being 0.83 cases per 1000 population, and this number of cases discovered is one tenth of the estimated total of 226000 cases in the whole country. The gun health centres, the largest in number and also with its subordinate subcentres fully mobilized, contributed more to the total national accomplishment than the health centre in cities. The efficiency in term of discovery rate was also higher in the gun health centres. Among the city health centres, those in large cities were the poorest because the per 1000 case rate and the proportion of cases discovered among the total estimated were the lowest, and this is mainly due to the relatively small number of health facilities and workers as compard with the size of population, 280000 per health centre in large cities as a whole and 430000 in Seoul City. This finding indicates an urgent need for corrective measures for such an unbalance in large cities.

\section{PART 2}

\section{Analysis of Accomplishments of Gun Health Centres}

As noted above, the gun health centres are the main forces in sputum case-finding in Korea, and 
결핵 및 호홉기질환 Vol. 17 , No. 2 , Ápril, 19370

Table 2. Distribution of Gun Health Centres by Average No. of Cases Discovered per Myon Per Year and by Province, 1969 (January-Decemer)

\begin{tabular}{|c|c|c|c|c|c|c|c|c|c|c|c|}
\hline \multirow{3}{*}{$\begin{array}{l}\text { Average } \\
\text { No. of cases } \\
\text { per myon } \\
\text { per year }\end{array}$} & \multicolumn{11}{|c|}{ Average No. of cases per myon per year } \\
\hline & \multirow{2}{*}{ Kyonggi } & \multirow{2}{*}{$\left|\begin{array}{c}\text { Kang- } \\
\text { won }\end{array}\right|$} & \multirow{2}{*}{\begin{tabular}{|c|} 
Choong- \\
Puk
\end{tabular}} & \multirow{2}{*}{$\begin{array}{c}\text { Choong- } \\
\text { Nam }\end{array}$} & \multirow{2}{*}{$\begin{array}{c}\text { Chun- } \\
\text { Puk }\end{array}$} & \multirow{2}{*}{\begin{tabular}{|c} 
Chun- \\
Nam
\end{tabular}} & \multirow{2}{*}{$\begin{array}{c}\text { Kyong- } \\
\text { puk }\end{array}$} & \multirow{2}{*}{$\begin{array}{c}\text { Kyong- } \\
\text { Nam }\end{array}$} & \multirow{2}{*}{ Cheju } & \multicolumn{2}{|c|}{ Total } \\
\hline & & & & & & & & & & \begin{tabular}{|l|l|} 
No. & | \\
\end{tabular} & $\%$ \\
\hline 0 & - & - & - & - & - & - & - & - & - & - & - \\
\hline 1 & - & - & - & - & - & - & - & - & - & - & - \\
\hline 2 & - & - & - & - & - & - & - & 1 & - & 1 & 0.7 \\
\hline 3 & - & - & - & - & - & - & - & 1 & - & 1 & 0.7 \\
\hline 4 & - & - & - & - & - & - & - & 1 & - & 1 & 0.7 \\
\hline 5 & - & - & - & - & - & - & - & 3 & - & 3 & 2.1 \\
\hline 6 & 3 & - & - & - & - & - & - & 1 & - & 4 & 2.9 \\
\hline 7 & 2 & 1 & 2 & 1 & 1 & 2 & - & 3 & - & 12 & 8.6 \\
\hline 8 & 2 & - & 1 & - & 2 & 1 & 1 & 2 & - & 9 & 6.4 \\
\hline 9 & 1 & 1 & 1 & - & - & 4 & - & 3 & - & 10 & 7.1 \\
\hline 10 & 3 & 1 & 1 & - & - & - & 1 & 1 & - & 7 & 5.0 \\
\hline 11 & 1 & - & 3 & - & 1 & 1 & - & 2 & - & 8 & 5.7 \\
\hline 12 & - & - & - & - & - & 2 & - & - & - & 2 & 1.4 \\
\hline 13 & 1 & 2 & - & 2 & 2 & 2 & - & 1 & 1 & 11 & 7.9 \\
\hline 14 & 1 & - & 1 & 2 & 1 & 1 & - & - & - & 6 & 4. 3 \\
\hline 15 & - & 1 & - & 2 & - & 3 & 2 & 1 & - & 9 & 6.4 \\
\hline 16 & - & 2 & - & 2 & 2 & 2 & 3 & - & - & 11 & 7.9 \\
\hline 17 & - & - & - & - & 1 & 1 & 1 & - & - & 3 & 2. 1 \\
\hline 18 & 1 & 3 & - & - & 2 & - & 1 & - & - & 7 & 5. 0 \\
\hline 19 & - & - & 1 & 1 & 1 & - & 5 & - & 1 & 9 & 6.4 \\
\hline 20 & - & - & - & 1 & - & - & 3 & - & - & 4 & 2.9 \\
\hline 21 & 2 & 2 & - & - & - & 1 & 4 & - & - & 9 & 6.4 \\
\hline 22 & 2 & - & - & 1 & - & 1 & 1 & - & - & 5 & 3.6 \\
\hline 23 & - & - & - & 1 & - & - & - & - & - & 1 & 0.7 \\
\hline 24 & - & - & - & 1 & - & 1 & - & - & - & 2 & 1.4 \\
\hline 25 & - & - & - & - & - & - & - & - & - & - & - \\
\hline 26 & - & - & - & - & - & - & - & - & - & - & - \\
\hline 27 & - & - & - & - & - & - & 1 & - & - & 1 & 0.7 \\
\hline 28 & - & - & - & 1 & - & - & - & - & - & 1 & 0.7 \\
\hline 29 & - & 1 & - & - & - & - & - & - & - & 1 & 0.7 \\
\hline 30 & - & 1 & - & - & - & - & - & - & - & 1 & 0.7 \\
\hline 31 & - & - & - & - & - & - & - & - & - & - & - \\
\hline 32 & - & - & - & - & - & - & - & - & - & - & - \\
\hline 33 & - & - & - & - & - & - & - & - & - & - & - \\
\hline 34 & - & - & - & - & - & - & - & - & - & - & - \\
\hline 35 & - & - & - & - & - & - & $\cdots$ & - & - & - & - \\
\hline 36 & - & - & - & - & - & - & 1 & - & - & 1 & 0.7 \\
\hline Total & 19 & 15 & 10 & 15 & 13 & 22 & 24 & 20 & 2 & 140 & 99.8 \\
\hline $\begin{array}{l}\text { Provincial ave- } \\
\text { rage No. of } \\
\text { cases per myon } \\
\text { per year }\end{array}$ & 10.4 & 15. $\mathrm{c}$ & 10.0 & 14.3 & 12.4 & 12.3 & 17.5 & 7.1 & 12.2 & 12.4 & \\
\hline
\end{tabular}


Table 3. Distribution of Gun Health Centres by Number of Specimens Collected and Number of Cases Discovered Per Myon Per Year (1969)

\begin{tabular}{c|r|r|r|r|r|r|r|r|r}
\hline $\begin{array}{c}\text { No. of specimens } \\
\text { collected per } \\
\text { myon per year }\end{array}$ & \multicolumn{7}{|c|}{ No. of case discovered per myon per year } \\
\cline { 2 - 7 } & $0 \sim 3$ & $4 \sim 7$ & $8 \sim 11$ & $12 \sim 15$ & $16 \sim 19$ & $20 \sim 23$ & $24 \sim 27$ & $28 \sim 36$ & Total \\
\hline $0 \sim 99$ & & & & & & & & & 0 \\
$100 \sim 199$ & 1 & 7 & 14 & 4 & 8 & 1 & & & 35 \\
$200 \sim 299$ & & 5 & 8 & 4 & 6 & 5 & & & 28 \\
$300 \sim 399$ & & 6 & 7 & 7 & 8 & 7 & & & 35 \\
$400 \sim 499$ & 1 & 2 & 7 & 4 & 3 & & 2 & 20 \\
$500 \sim 599$ & & & 3 & 5 & 2 & 2 & 1 & & 13 \\
$600 \sim 699$ & & 1 & & & 1 & & 1 & & 3 \\
$700 \sim 799$ & & & & & 1 & 1 & 1 & 1 & 4 \\
$800 \sim 899$ & & & & 1 & & & & & 1 \\
$900 \sim 1000$ & & & & & & & & 1 & 1 \\
Total & 20 & 34 & 28 & 30 & 19 & 3 & 4 & 140 \\
\hline
\end{tabular}

with more than one thousand of myon health subcentres available, even higher accomplishments can be expected of gun health centres. For this reason, more detailed analysis is made of the achievements of gun health centres in 1969 .

As seen in Table 2, 12.4 cases were discovered per myon per year for the country as a whole, or approximately 1.0 cases per month, which is only half the target of 2 cases per myon per month, or 24 cases per year. Only 7 health centres reached this target as seen in Table 2.

Kyongsang Pukdo showed the best achievements, a discovery of 17.5 cases per myon per year, and Kyongsang Namdo the poorest, only 7.7 cases. Choongchung Namdo and Kangwondo also showed good results, 15 and 14 cases, respectively.

For the country as a whole, half of the total of 140 gun health centres showed a discovery of less than 14 cases per myon per worker, and the other half 14 cases or more. The best heasth centre was the Seunsan Health Centre in Kyongsang Pukdo with a discovery of 36 cases per myon per year, and the poorest was the the Hamyang Health Centre and the Kosung Health Centre in Kyongsang Namdo With a discovery of 2 and 3 cases only.

In order to see whether the number of cases discovered was in proportion to the number of specimens collected, a correlation table was made and shown in Table 3. Intervals of 100 specimens and of 4 cases were arbitrarily used for classification of the numbers of specimens collected and the numbers of cases discovered, respectively, because of the average discovery rate for the gun heaath centres in 1969 was $4.1 \%$, that means that it would be possible to discover approximately 4 cases by examination of 100 specimens.

As seen in Table 3, 30 health centres are on the diagonal line, and 63 above and 47 below that line, or $21.4 \%, 45.0 \%$ and $33.6 \%$, respectively. This means that the number of cases discovered is not closely correlated with the number of specimens collected. For example, the best achievement shown by the Seunsan Gun Health Centre, i. e., a discovary of 36 cases per myon per year, was made by examination of 436 specimens only, with a discovery rate of $8.2 \%$, whereas the poorest achievement shown by the Hamyang Health Centre were the combined results of both the small number of specimens collected and the low discovery rate, 2 cases from 114 specimens, the discovery rate being $1.0 \%$.

In conclusion, to discover more cases, collection of a sufficient number of sputm specimens is necessary but more important is to collect good specimens from right persons and examine them carefully so that a fairly reasonable rate can be obtained, If all 
the myon workers should work along this guideline, it should not be difficult to reach the target of 24 cases per myon per year. Then, the total number of cases to be discovered will be 35352 or 15039 more than the accomplishment in 1969 or $42.5 \%$ increase.

Thus, together with the improvement of sputum case-finding activities in the cities, this aspect of tuberculosis control will show further a step-forward, and it may be possible to discover one fifth of the estimated total each year. By giving treatment to all the infectious cases discovered, this will really exert a strong epidemiological impact on tuberculosis, and realize the successful control of tuberculosis in this country.

\section{Discussion}

We know now that the important source of infection is one who has a cough and is excreting tubercle bacilli in his sputum, which are mostly demonstrable on direct smear microscopy. Cases whose sputum is positive only on culture are relatively weak in its infectivity and, therefore, do not pose a serious danger to the community. Cases diagnosed on radiography alone with negative bacteriology are certainly non-infectious and in all probability not suffering from tuberculosis. The diagnostic value of $\mathrm{X}$-ray cannot be denied, particularly for minimal pulmonary pathology. The question, however, remains that our country has neither a sufficient number of $\mathrm{X}$-ray units to reach remote areas nor capacity of treatment to include all the unimportant suspects dicovered by $\mathrm{X}$ ray examination. Direct smear microscopy of sputum produced by symptom motivated persons suffering from a cough for more than two weeks is certainly the most productive way of idenitifying the sources of infection. Studies have shown that more than $90 \%$ of all the infectious cases in a community have symptoms and would voluntarily seek relief of their symptoms at the health center if they have a confidence in it and the service provided is readily available, convenient, courteous and free of charge.
In Korea, there are more than 226000 infectious tuberculosis cases(1965 survey data) widely scattered throughout the country, while medical and health facilities are usually limited and concentrated in the cities. From the epidemiological point of view, discovery of the undiscovered cases is the most urgent task, which, combined with thorough treatment of those thus discovered, would lead to the rapid reduction of tuberculosis in Korea. During 1969, 665750 persons with symptom were examined by sputum test, and out of whom 24313 cases of tuberculosis were discovered. These new cases discovered by laymen in 1969 represent approximately $11 \%$ of the estimated total of infectious cases in the country. An average of 126 new cases were discovered by each health center and every myon worker discovered an average of 12 cases per year. This is really a great achievement in terms of productivity, cost and efficiency. For the more efficient conduct of the programme in the future the writer, wishes to bring out the following points for consideration:

1) The public must be well informed of the value and the accurracy of the diagnostic method for pulmonary tuberculosis and the forthcoming availity of such a service in their community.

2) Sputum collectors should teach the patients on how to raise the sputum from the bottom of the chest.

3) The workers should be thoroughly oriented in every step of the procedures, such as, talk to the public, collection of specimens, recordkeeping, slide labelling, smear preparation, staining, and the use and care of microscope, microscopic examination of the standard slides, etc.

4) For efficient work to be expected of the auxiliary workers, regular and close supervision of their performance by TB supervisory medical officers and technicians of provincial TB laboratory are vitally important.

5) To encourage the workers, provision of incentives should be considered. 